\title{
IMMINENCE IN REFUGEE AND HUMAN RIGHTS LAW: A MISPLACED NOTION FOR INTERNATIONAL PROTECTION
}

\author{
Adrienne Anderson*, Michelle Foster $\diamond$, Hélène Lambert§ And \\ JANE MCADAM ${ }^{\circ}$
}

\begin{abstract}
This article is an output of a major research project examining the notion of imminence in the law on international protection. It is the first piece of scholarship to identify an emerging trend, namely the introduction of imminence-whether invoked implicitly or explicitlyas a potential barrier to refugee status or complementary protection. The article analyses the jurisprudence of relevant international bodies and courts and critiques the validity of this notion as a tool for assessing States' protection obligations.
\end{abstract}

Keywords: complementary protection, human rights law, imminence, non-refoulement, refugee law, time.

\section{INTRODUCTION}

Time is everywhere in refugee and human rights law. ${ }^{1}$ But in assessing whether someone faces a real chance of being persecuted or subjected to other serious harm if removed, the immediacy or 'imminence' of that harm should not be the

* BA, LLB (Hons) (Auckland), LLM (Mich); Research Associate, Andrew \& Renata Kaldor Centre for International Refugee Law, Faculty of Law, UNSW Sydney and PhD candidate, University of Melbourne Law School. This article was produced under the auspices of an Australian Research Council (ARC) Discovery Grant on "The Concept of "Imminence" in the International Protection of Refugees', DP160100079. We acknowledge the generous support of the ARC, and thank Mimi Oorloff, JD student, Melbourne Law School, for excellent editorial assistance.

$\checkmark$ LLB, BCom (Hons) (UNSW), LLM, SJD (Mich); Professor and Director, Peter McMullin Centre on Statelessness, Melbourne Law School, The University of Melbourne.

$\S$ Maitrise (Droit Public) (Strasbourg), PhD (Exeter); Professor of Law, University of Wollongong and Professor of International Law, University of Westminster, London.

- BA (Hons), LLB (Hons) (Syd), DPhil (Oxf); Scientia Professor and Director, Andrew \& Renata Kaldor Centre for International Refugee Law, Faculty of Law, UNSW Sydney. We would like to express our enormous gratitude to the participants at our expert workshop held at UNSW in August 2018, who generously gave of their time and expertise in helping us to refine our framing and understanding of these issues. We also thank Christopher Michaelsen for suggesting we refer to the 'notion' rather than the 'concept' of imminence. We also thank the anonymous reviewers who made very valuable suggestions. Any mistakes of course remain our own.

1 B Burson, 'The Concept of Time and the Assessment of Risk in Refugee Status Determination' (Kaldor Centre Annual Conference, Sydney, 18 November 2016) 1-2, $4<\mathrm{http}: / / w w w . k a l d o r c e n t r e$. unsw.edu.au/sites/default/files/B_Burson_2016_Kaldor_Centre_Annual_Conference.pdf $>$ (writing in his personal capacity). 
basis on which protection is granted or denied. ${ }^{2}$ A decision-maker who took such an approach would fall into legal error. ${ }^{3}$

We are struck, however, by several types of protection cases in which the nearness in time of harm seemed to play a role, such as those relating to the (future) impacts of climate change and to deterioration of health over time. We are curious about why, and how, the 'imminence' of harm was factored into decision-making in this context-either implicitly or explicitly. What was common to these cases was that the alleged harm was not felt acutely now, but, it was argued, it would have deleterious consequences in the future.

Decision-makers may have imported the notion of imminence, understood in terms of time (when harm may occur), from other areas of international law, such as the law of self-defence. ${ }^{4}$ Yet, even in that context, there is 'little scholarly consensus on what is properly meant by "imminence" in the context of contemporary threats'. ${ }^{5}$ Indeed, we are surprised by how little jurisprudential discussion there has been of the notion, finding that it has instead been promoted through academic debate rather than legal instruments or case law. In the 'protection of civilians'/peacekeeping context, where the United Nations (UN) Security Council has traditionally directed peacekeepers to protect civilians from 'imminent threat of physical violence'6 — by 'us[ing] force to protect civilians who were on the brink of being harmed' 7 - the notion has again proven to be problematic and poorly understood, ${ }^{8}$ at times creating confusion about when to act. For this reason, 'imminence' is now

2 By 'protection' or 'international protection', we mean the protection granted to refugees and others at risk of serious harm, based on the principle of non-refoulement in refugee and human rights law (refugee status and complementary protection, respectively).

3 By 'decision-maker', we mean refugee and immigration decision-makers (typically immigration officials), tribunal members, and judges who consider international protection claims.

4 An imminent threat of attack may justify the use of self-defence by a State: $\mathrm{Mr}$ Barker to $\mathrm{Mr}$ Woodbury-(Extract), H Ex Doc No 74, 25th Cong, 2nd Sess, better known as the Caroline case. The nearness in time of the attack seems to demand something 'instant, overwhelming, and leaving no choice of means, and no moment of deliberation': remarks by the United States Secretary of State on the conditions under which a plea of self-defence could be accepted (in relation to the Caroline incident), cited in AC Arend, 'International Law and the Preemptive Use of Military Force' (2003) 26(3) WashULQ 89, 90-1. See also J Wright, 'The Modern Law of Self-Defense' (IISS London, 11 January 2017) <https:/www.gov.uk/government/speeches/attorney-generals-speech-at-theinternational-institute-for-strategic-studies $>$.

5 D Bethlehem, 'Self-Defense Against an Imminent or Actual Armed Attack by Nonstate Actors' (2012) 106 AJIL 770, 773. Akande and Liefländer agree that due to the lack of scholarly consensus, the notion of imminence 'needs to be further refined and developed': D Akande and T Liefländer, 'Clarifying Necessity, Imminence, and Proportionality in the Law of Self-Defense' (2013) 103 AJIL 563, 564.

6 First used October 1999 in UN Security Council (UNSC) Res 1270 (22 October 1999) UN Doc S/RES/1270 para 14. See H Willmot et al. (eds), Protection of Civilians (Oxford University Press 2016).

7 V Holt and G Taylor, Protecting Civilians in the Context of UN Peacekeeping Operations: Successes, Setbacks and Remaining Challenges (United Nations 2009) 40 (emphasis added, fn omitted).

8 ibid 166, 307, 327. 
rarely invoked in that context. ${ }^{9}$ Our concern is that an already unclear notion may be unwittingly transposed into the law on international protection, resulting in poor decision-making, legal error, and, ultimately, negative outcomes for refugees and others in need of protection.

For these reasons, this article engages with issues that go well beyond academic inquiry alone: they have immediate and concrete consequences for people whose protection claims are rejected because of a lack of legal clarity about the relevance, nature, and scope of the notion of imminence. A series of cases in New Zealand has already started to delineate the potential of refugee and human rights law to protect people displaced from small Pacific Island countries by the impacts of climate change, disasters, and environmental degradation. ${ }^{10}$ While no one has yet been granted protection on these grounds, this jurisprudence provides the most comprehensive analysis of the issues to date. 'Imminence' has been discussed specifically in this context, with the Immigration and Protection Tribunal (Tribunal) observing (rightly, in our view) that it imposes no higher threshold than the well-founded fear test in refugee law, and requires 'no more than sufficient evidence to establish substantial grounds for believing the appellant would be in danger'. ${ }^{11}$ However, in other jurisdictions, imminence has operated

9 The term 'imminent' has been removed, for example, from the mandates of UN missions in Sudan (UNMIS), Darfur (UNAMID), Central African Republic (MINUSCA), Côte d'Ivoire (UNOCI), and the Democratic Republic of the Congo (MONUSCO). See UNSC Res 1706 (31 August 2006) UN Doc S/RES/1706 para 12(a); UNSC Res 1769 (31 July 2007) UN Doc S/RES/ 1769 para 15(a)(ii); UNSC Res 2149 (10 April 2014) UN Doc S/RES/2149 para 30(a)(i); UNSC Res 2162 (25 June 2014) UN Doc S/RES/2162 para 19(a)(i); UNSC Res 2147 (28 March 2014) UN Doc S/RES/2147 para 4(a)(i) as cited in S Sheeran and C Kent, 'Protection of Civilians, Responsibility to Protect, and Humanitarian Intervention Conceptual and Normative Interactions' in Willmot et al. (n 6) 45, n 138. Moreover, where it is still invoked, the term 'imminent' in this context has been more recently defined to encompass more than an immediate time frame: "The protection of civilians [POC] mandate often specifies an "imminent" threat of physical violence. A POC threat is considered imminent as soon as the mission has a reasonable belief that a potential perpetrator displays a hostile intent, capacity, historical record and opportunity to inflict physical violence. The term "imminent" does not therefore imply that violence is guaranteed to happen in the immediate or near future or is being carried out. A threat of violence against civilians is imminent from the time it is identified until such time that the mission can determine that the threat no longer exists': United Nations Department of Peacekeeping Operations/Department of Field Support, 'DPKO/DFS Policy on the Protection of Civilians in United Nations Peacekeeping' 2015.07 (1 April 2015) para 47; United Nations Department of Peacekeeping Operations/Department of Field Support, 'Protection of Civilians: Implementing Guidelines for Military Components of United Nations Peacekeeping Missions’ 2015.02 (February 2015) 25.

$10 * A C$ (Tuvalu) [2014] NZIPT 800517; AF (Kiribati) [2013] NZIPT 800413; AF (Tuvalu) [2015] NZIPT 800859; *BG (Fiji) [2012] NZIPT 800091; Teitiota $v$ Chief Executive of the Ministry of Business, Innovation and Employment [2013] NZHC 3125; Teitiota $v$ Chief Executive of the Ministry of Business, Innovation and Employment [2014] NZCA 173; Teitiota $v$ Chief Executive of the Ministry of Business, Innovation and Employment [2015] NZSC 107. Note that an asterisked New Zealand case means that it is a precedent. Australian and New Zealand authorities have considered cases on this issue at least as far back as 1995, as discussed in J McAdam, 'The Emerging New Zealand Jurisprudence on Climate Change, Disasters and Displacement' (2015) 3 Migration Studies 131.

${ }^{11} A F$ (Kiribati) (n 10), para 90. 
inappropriately as an additional hurdle for people seeking international protection. $^{12}$

This article is the product of a project examining the notion of imminence in the protection of refugees and other forced migrants. That project is based on the hypothesis that the notion has been introduced haphazardly, and virtually unnoticed, into refugee and human rights law, with no legal or conceptual foundation. While at times decision-makers' use of the term may simply be loose language that has no particular import in the decision itself, at other times, it is being used to deny protection. Furthermore, there is a danger that loose language may risk the notion being used more substantively.

Beyond its scholarly contribution, we hope that this conceptual article will help to sharpen the focus of decision-makers when considering issues of time and risks of harm in protection cases, and the implications of using the notion of imminence in deciding whether or not individuals require international protection.

\section{SCOPE AND METHODOLOGY}

The Refugee Convention remains the 'cornerstone of the international refugee protection regime'. ${ }^{13}$ However, due to its relatively restrictive definitionwhich requires a person to establish a 'well-founded fear' of being persecuted for reasons of his or her race, religion, nationality, political opinion, or membership of a particular social group - it has been supplemented by international and regional human rights law, which has stepped in to fill certain gaps by protecting people against return to a 'real risk' of (inter alia) being subjected to torture or other cruel, inhuman or degrading treatment or punishment, or being arbitrarily deprived of their life (known as complementary protection). ${ }^{14}$

This article begins by exploring whether the evidentiary standards relevant to assessing claims for international protection, namely 'well-founded fear' and 'real risk', inherently contain an imminence component. It then examines jurisprudence from international and supranational courts and bodies assessing claims for international protection in which the notion of imminence has formed part of the reasoning, either explicitly or implicitly.

12 See discussion below in Pt IV.

13 Convention Relating to the Status of Refugees (adopted 28 July 1951, entered into force 22 April 1954) 189 UNTS 137, read in conjunction with the Protocol Relating to the Status of Refugees (adopted 31 January 1967, entered into force 4 October 1967) 606 UNTS 267 (together, Refugee Convention); UN High Commissioner for Refugees (UNHCR) EXCOM Conclusion No 103 (LVI) 'Conclusion on the Provision on International Protection Including Through Complementary Forms of Protection' (2005) Preamble.

14 For an overview, see J McAdam, 'Human Rights and Forced Migration' in E FiddianQasmiyeh et al. (eds), The Oxford Handbook of Refugee and Forced Migration Studies (Oxford University Press 2014); J McAdam, Complementary Protection in International Refugee Law (Oxford University Press 2007). 
The jurisdictions examined are the UN Human Rights Committee (UNHRC), the UN Committee against Torture (UNCAT), the European Court of Human Rights (ECtHR), and the Court of Justice of the European Union (CJEU). ${ }^{15}$ They were chosen because: (a) they represent decision-making with respect to non-return to a 'real risk' of harm (which is directly relevant to refugee law and the 'well-founded fear' test), drawing on international law and/or European Union (EU) law; (b) they invoke the notion of imminence in their decisions, whether implicitly or explicitly; and (c) their decisions are publicly accessible, enabling an in-depth assessment of relevant decisions from each jurisdiction.

Each selected jurisdiction has its own treaty framework and distinctiveness. The UNHRC, a body of independent experts that monitors States' implementation of the International Covenant on Civil and Political Rights (ICCPR), ${ }^{16}$ can consider individual complaints about alleged violations by States that are parties to its First Optional Protocol. ${ }^{17}$ In the present context, the most relevant allegations arise in relation to Articles 6 and 7 of the ICCPR, which, respectively, protect the right to life, and the right not to be subjected to torture or cruel, inhuman or degrading treatment or punishment.

The UNCAT, established by Article 17 of the Convention against Torture (CAT), ${ }^{18}$ may 'receive and consider communications from or on behalf of individuals' subject to the jurisdiction of any State that has made a relevant declaration pursuant to Article 22. For present purposes, the relevant provision is Article 3 which provides that '[n]o State Party shall expel, return ("refouler") or extradite a person to another State where there are substantial grounds for believing that he would be in danger of being subjected to torture'.

In Europe, Articles 2 and 3 of the European Convention on Human Rights (ECHR) respectively protect the right to life, and the right not to be subjected to torture or inhuman or degrading treatment or punishment. ${ }^{19}$ Both have been acknowledged as extending to protect individuals from removal to a real risk of such harm ${ }^{20}$ - in other words, they have a non-refoulement component. This protection may be present in other rights as well: indeed, the ECtHR has expressly acknowledged this possibility with respect to Article 4 (prohibition of slavery and forced labour), ${ }^{21}$ Article 5 (right to liberty

15 The next element of the project is to examine State practice through case law in Australia, Canada, France, Germany, New Zealand, the United Kingdom, and the United States.

16 International Covenant on Civil and Political Rights (adopted 16 December 1966, entered into force 23 March 1976) 999 UNTS 171.

17 Optional Protocol to the International Covenant on Civil and Political Rights (adopted 16 December 1966, entered into force 23 March 1976) 999 UNTS 171.

${ }^{18}$ Convention against Torture and Other Cruel, Inhuman or Degrading Treatment or Punishment (adopted 10 December 1984, entered into force 26 June 1987) 1465 UNTS 85.

${ }^{19}$ Convention for the Protection of Human Rights and Fundamental Freedoms (adopted 4 November 1950, entered into force 3 September 1953) ETS No 5 (European Convention on Human Rights, as amended).

${ }_{20}^{20}$ Soering $v$ United Kingdom (1989) 11 EHRR 439, paras 91, 113.

21 Ould Barar v Sweden (1999) 28 EHRR CD213. 
and security), ${ }^{22}$ Article 6 (right to a fair trial), ${ }^{23}$ Article 7 (no punishment without law), ${ }^{24}$ Article 8 (right to respect for private and family life), ${ }^{25}$ and Article 9 (right to freedom of thought, conscience and religion). ${ }^{26}$ However, whereas in a claim based on Articles 2 or 3 an applicant must show that there are 'substantial grounds' for believing that he or she would face a real ('foreseeable') ${ }^{27}$ risk of being subjected to the relevant harm, ${ }^{28}$ a claim based on the other provisions demands a much higher standard - a 'flagrant breach' or a 'disproportionate breach' of a right — which has rarely been met. ${ }^{29}$ In many cases, violations of these other rights will already be encapsulated by the prohibition on removal to 'inhuman or degrading treatment' in Article 3, 30 which is why such cases are the primary focus in Part IV below. ${ }^{31}$

In the EU, the CJEU, through its preliminary reference procedure, answers questions referred to it by the national courts of EU Member States seeking clarification of the interpretation of EU law. ${ }^{32}$ The cases pertinent to the present article relate primarily to the interpretation of the Qualification Directive, ${ }^{33}$ which protects third-country nationals recognized as refugees ${ }^{34}$ and beneficiaries of 'subsidiary protection'. ${ }^{35}$ The latter are people who cannot be removed because there are 'substantial grounds ... for believing'

\footnotetext{
22 Tomic v United Kingdom, App No 17837/03, Decision of 14 October 2003; El-Masri v Macedonia (2013) 57 EHRR 25.

23 Soering (n 20); Drozd and Janousek v France and Spain (1992) 14 EHRR 745; Einhorn v France, App No 71555/01, Decision of 16 October 2001; Mamatkulov v Turkey (2005) 41 EHRR 25; Al-Moayad v Germany (2007) 44 EHRR SE22; Stapleton v Ireland (2010) 51 EHRR SE4; Othman v United Kingdom (2012) 55 EHRR 1.

24 Gabarri Moreno v Spain (2004) 39 EHRR 40.

${ }^{25}$ Fv United Kingdom, App No 17341/03, Decision of 22 June 2004.

26 Z United Kingdom, App No 27034/05, Decision of 28 February 2006.

27 Soering (n 20) para 100.

28 ibid (extradition); Cruz Varas $v$ Sweden (1991) 14 EHRR 1; Chahal v United Kingdom (1996) 23 EHRR 413; Ahmed v Austria (1997) 24 EHRR 278 (expulsion). See E Lauterpacht and D Bethlehem, 'The Scope and Content of the Principle of Non-Refoulement: Opinion' in E Feller, V Türk and F Nicholson (eds), Refugee Protection in International Law: UNHCR's Global Consultations on International Protection (Cambridge University Press 2003) paras 246, $249,252$.

29 Othman (n 23); El-Masri (n 22); Al Nashiri v Poland, App No 28761/11, Judgment of 24 July 2014; Husayn (Abu Zubaydah) v Poland, App No 7511/13, Judgment of 24 July 2014.

${ }^{30} Z$ (n 26); see also $R v$ Special Adjudicator, ex parte Ullah [2004] 2 AC 323. Multiple rights may, however, be breached: see eg El-Masri (n 22).

31 For an excellent and comprehensive overview of the scope of non-refoulement in the ECHR, see C Costello, The Human Rights of Migrants and Refugees in European Law (Oxford University Press 2016).

32 Consolidated Version of the Treaty on the Functioning of the European Union [2008] OJ C115/47, art 267 (ex art 234 TEC).

33 The European Parliament and the Council Directive 2011/95/EU of 13 December 2011 on Standards for the Qualification of Third-Country Nationals or Stateless Persons as Beneficiaries of International Protection, for a Uniform Status for Refugees or for Persons Eligible for Subsidiary Protection, and for the Content of the Protection Granted [2011] OJ L 337/9 (Qualification Directive).

34 ibid art 2(d) (which incorporates the definition of a refugee in art $1 \mathrm{~A}(2)$ of the Refugee Convention, subject to restricting its application in this context to third-country nationals) and arts 9-10. 35 ibid art 15.
} 
that they 'would face a real risk of suffering serious harm', ${ }^{36}$ namely (a) the death penalty or execution; (b) torture or inhuman or degrading treatment or punishment; or (c) a 'serious and individual threat to a civilian's life or person by reason of indiscriminate violence in situations of international or internal armed conflict'. ${ }^{37}$ A significant difference between EU law and the ECHR is that the grant of refugee status or subsidiary protection status under the Qualification Directive results in a specific set of rights and benefits for beneficiaries, of which protection against refoulement is just one. The situation is notably different under the ECHR, which only provides for protection against refoulement. ${ }^{38}$

\section{TIME AND RISK ASSESSMENT IN INTERNATIONAL PROTECTION CASES}

The notion that 'time' is relevant to the assessment of international protection is not new; rather, it is central to many aspects of both the refugee definition and the broader protection regime. ${ }^{39}$ As Durieux has observed, refugee situations 'are exceptional circumstances in international relations' and, as such, 'are necessarily temporary'. ${ }^{40}$ Indeed, the UN High Commissioner for Refugees (UNHCR), the body vested with the responsibility to supervise the application of the Refugee Convention, was initially established as a temporary entity with a three-year mandate, which was subsequently extended in five-year increments until 2004 when it finally became openended. ${ }^{41}$ The cessation clauses of the Refugee Convention envisage that an individual's need for international protection may be temporary: for instance, refugee status may end if the circumstances in the country of origin change fundamentally. ${ }^{42}$ Contemporary debates about temporary protection, accelerated procedures, and durable solutions all invoke the concept of time as a central factor in refugee protection.

In terms of the substantive assessment of who is a refugee, time permeates every aspect of the refugee status determination (RSD) process:

36 ibid art 2(f).

37 ibid art 15.

38 This is also the case under arts 4 and 19(2) of the European Union (EU) Charter of Fundamental Rights which guarantee protection against refoulement but not necessarily a status akin to that under the Qualification Directive: Charter of Fundamental Rights of the European Union [2000] OJ C364/01.

39 There is also an increasing interest in time in international law more generally: see for example, M Ambrus and RA Wessel (eds), Netherlands Yearbook of International Law 2014: Between Pragmatism and Predictability: Temporariness in International Law (TMC Asser Press 2015) vol 45. In refugee law, see eg J-F Durieux and J McAdam, 'Non-Refoulement Through Time: The Case for a Derogation Clause to the Refugee Convention in Mass Influx Emergencies' (2004) 16 IJRL 4; J-F Durieux, 'Time in the Refugee Regime' (Keynote address, Andrew \& Renata Kaldor Centre for International Refugee Law Annual Conference, 18 November 2016).

40 J-F Durieux, 'Protection Where? - or When? First Asylum, Deflection Policies and the Significance of Time' (2009) 21 IJRL 75, 75.

${ }_{41}$ United Nations General Assembly (UNGA) Res 58/153, UN Doc A/RES/58/153 (22 December 2003).

42 Refugee Convention, art 1C; see also arts 1D, $1 \mathrm{E}$. 
On the one hand, time points backwards because refugee claims are grounded in what has happened in the past. ... RSD, however, also faces forward in time. It reaches into the future and inquires as to the predicament of the claimant in his or her country of origin. Refugee status is recognised precisely because the future there for the claimant is anticipated to be one in which some form of serious harm will accrue to him or her at some projected point in time arising from a failure of the state of origin to protect the enjoyment of his or her fundamental human rights by reason of a Convention-protected ground..$^{43}$

The maxim that assessing a well-founded fear of persecution involves a forward-looking assessment of risk is well entrenched, yet there is little analysis of how far forward the assessment may extend, or what the role of time is in that prospective assessment. In light of the lack of explicit consideration of these issues, we begin our analysis by reflecting on whether there is there anything inherent in either the 'well-founded fear' or 'real risk' tests - the so-called 'standard of proof' in international protection claimsthat provides answers to these questions.

The well-founded fear test in refugee law clearly entails a prospective and forward-looking assessment. Indeed, it has been stated that any refugee determination is necessarily an 'essay in hypothesis, an attempt to prophesy what might happen to the applicant in the future, if returned to his or her country of origin'. ${ }^{44}$ Therefore, a degree of speculation about future risk does not preclude a protection need from being recognized. However, other than these broad forms of guidance, it is striking that while there is a significant body of both jurisprudence and scholarship analysing a number of contentious aspects of the well-founded fear test, comparatively little has been written about the role of time itself. ${ }^{45}$ Instead, debates about the 'wellfounded fear' test have centred on: (a) whether it entails a subjective notion or is entirely objective, ${ }^{46}$ (b) the necessary degree of likelihood to establish

43 Burson (n 1) 1-2.

44 GS Goodwin-Gill and J McAdam, The Refugee in International Law (3rd edn, Oxford University Press 2007) 54.

45 Hathaway and Foster refer to the 'distant future' (JC Hathaway and M Foster, The Law of Refugee Status (2nd edn, Cambridge University Press 2014) 123); Wouters refers to the 'near future' (K Wouters, International Legal Standards for the Protection from Refoulement (Intersentia 2009) 26). Hathaway and Foster observe that 'the inquiry should not focus just on present risks, but also on such risks as may well eventuate': 123. Goodwin-Gill and McAdam also note that 'the element of well-foundedness looks more to the future, than to the past': Goodwin-Gill and McAdam (n 44) 63; see also 54. Zimmermann and Mahler simply note that 'the term "fear" expresses a forward-looking expectation of risk': A Zimmermann and C Mahler, 'Article 1 A, Para 21951 Convention' in A Zimmermann (ed), The 1951 Convention Relating to the Status of Refugees and Its 1967 Protocol: A Commentary (Oxford University Press 2011) 341.

46 Some scholars interpret 'fear' as 'apprehension' rather than subjective fear: see for example Hathaway and Foster (n 45) 105-6 and G Noll, 'Evidentiary Assessment under the Refugee Convention: Risk, Pain and the Intersubjectivity of Fear' in G Noll (ed), Proof, Evidentiary Assessment and Credibility in Asylum Procedures (Martinus Nijhoff 2005) 152. Whereas the preponderance of scholars (as well as judicial authority) takes the view that there is a subjective element to the fear requirement: see for example Goodwin Gill and McAdam (n 44) 63-4 and 
that a fear/risk is 'well-founded';47 and (c) evidentiary issues, including past persecution and generalized violence. ${ }^{48}$

It is in relation to the degree of likelihood that one would assume a consideration of time would most likely be found. In perhaps the most cited decision on this topic, the United States Supreme Court in Cardoza-Fonseca explained that:

There is simply no room in the United Nations' definition for concluding that because an applicant only has a $10 \%$ chance of being shot, tortured, or otherwise persecuted, that he or she has no 'well-founded fear' of the event happening ... [A] moderate interpretation of the 'well-founded fear' standard would indicate 'that so long as an objective situation is established by the evidence, it need not be shown that the situation will probably result in persecution, but it is enough that persecution is a reasonable possibility'. ${ }^{49}$

That the well-founded fear test requires only 'a reasonable possibility' of persecution, rather than the likelihood of harm, is an approach that has been widely replicated, with a variety of interchangeable tests effectively amounting to one of 'real chance'. ${ }^{50}$ While excluding risks that amount to 'sheer speculation', situations where there is only a 'bare possibility' of harm, or where the risk is 'so slight that it could be discounted', 51 it is an appropriately liberal test that reflects the protective objective of the refugee definition and the inherent challenges in establishing a future risk of persecution with any certainty.

Analysis of the 'well-founded fear' test has tended not to invoke concepts of directness of harm, necessity, or any indication of when a risk needs to eventuate. It is possible that a risk becomes more 'remote' or speculative, and thus less likely, the further into the future it is anticipated, but imminence-in the sense of timing - has not and cannot be assumed to constitute an inherent aspect of the well-founded fear test. Rather, that test would appear to be sufficiently open-textured to accommodate a longer-frame assessment of future risk. It thus appears capable of encompassing the evolving nature of many contemporary forms of slower-onset harms which may present less immediate, but no less serious, risks to human rights.

How does the well-founded fear test relate to the parallel 'real risk' test in the context of non-refoulement under human rights law (complementary

Zimmermann (n 45) 174. For the most comprehensive analysis of the issue, see JC Hathaway, 'Michigan Guidelines on Well-Founded Fear' (2005) MichJIntlL 492 and the related article, JC Hathaway and W Hicks, 'Is There a Subjective Element in the Refugee Convention's Requirement of "Well-Founded Fear"?' (2005) 26 MichJIntlL 505.

47 In this context the key issue in the scholarship has been the relationship between the 'wellfounded fear' test in the Refugee Convention and other tests adopted in international human rights law, see for example, Wouters (n 45) 25-6; 83-5. See also (n 52).

48 For a detailed discussion of these issues, see Hathaway and Foster (n 45) 161-81.

49 Immigration and Naturalization Service v Cardoza-Fonseca 480 US 421 (1987) at 440 per Stevens J.

${ }^{50}$ Hathaway and Foster (n 45) 113. 
protection)? While the Refugee Convention itself provides the test for refugee law, namely, a well-founded fear of being persecuted, there is no clear test provided in most of the relevant human rights treaties due to the fact that the non-refoulement obligations derived from the ICCPR and ECHR are implied from other, primary obligations (such as the right not to be subjected to torture). The exception is CAT, where Article 3 explicitly provides that no State shall expel or return a person to another State 'where there are substantial grounds for believing that he would be in danger of being subjected to torture'.

Just as the well-founded fear test has spawned a considerable literature, the real risk test has similarly stimulated analysis of matters such as whether there is a subjective or purely objective element, ${ }^{52}$ whether the evidentiary threshold should vary depending on the gravity of harm, ${ }^{53}$ and how precisely the relevant standard of likelihood of harm should be framed. In relation to the last of these, there has been some debate as to whether the 'real risk' test represents a higher threshold for applicants than the well-founded fear test, ${ }^{54}$ although the better view is that they should be equivalent. ${ }^{55}$ Insofar as there is a further gloss on the meaning of real risk, it is the notion of foreseeability - not imminence that is most often invoked. ${ }^{56}$ Yet, foreseeability in and of itself does not denote a particular timeframe.

52 For example, McAdam, Complementary Protection (n 14) argues that the 'substantial grounds' test in the Qualification Directive is 'an objective one' by contrast to the Refugee Convention: see at 61-3. By contrast Cherubini disagrees that the test as embodied in the Qualification Directive 'clearly rules out the existence of subjective elements': F Cherubini, Asylum Law in the European Union: From the Geneva Convention to the Law of the EU (Taylor and Francis 2014) 203.

53 Several scholars argue that the evidentiary threshold should vary depending on the severity of treatment, that is, the more severe the consequences, the lower the threshold should be. The core piece appears to be T Einarsen, 'The European Convention on Human Rights and the Notion of an Implied Rights to de facto Asylum' (1990) 2 IJRL 361, 371. Several commentators cite this piece as authority for that proposition: see for example Goodwin Gill and McAdam (n 44) 314; A Fabbricotti, 'The Concept of Inhuman or Degrading Treatment in International Law and its Application in Asylum Cases' (1998) 10 IJRL 637, 646; and D Weissbrodt and I Hortreiter, 'The Principle of Non-Refoulement: Article 3 of the Convention against Torture and other Cruel, Inhuman or Degrading Treatment or Punishment in Comparison with the Non-Refoulement Provisions of Other International Human Rights Treaties, (1999) 5 BHRLR 1, 14.

54 For helpful discussion of this issue, see in particular, H Battjes, European Asylum Law and International Law (Martinus Nijhoff 2006) paras 277-285; and Costello (n 31) 178-9.

55 The UNHCR has stated that 'there is no basis for adopting a stricter approach to proving risk in cases of complementary protection than there is for refugee protection': UNHCR, 'Submission to the Migration Amendment (Complementary Protection) Bill 2009 Inquiry' (30 September 2009) para 34, $<$ http://www.aph.gov.au/DocumentStore.ashx?id=f175865d-d80b-43b6-b845-fda2049ab713>. The jurisprudence of the various international supervisory bodies supports the view that it is, at least in theory, the same standard as 'real chance' in the Refugee Convention. For a detailed summary of the case law, see Andrew \& Renata Kaldor Centre for International Refugee Law, 'Submission in relation to the Migration Amendment (Protection and Other Measures) Bill 2014' (4 August 2014) paras 43-73, $<$ http://www.kaldorcentre.unsw.edu.au/sites/default/files/

migration_amendment_protection_and_other_measures_bill_2014_submission_final_0.pdf>.

56 For example in the seminal Soering decision (n 20), the United Kingdom government had argued that 'the application of Article 3 (art. 3) in extradition cases should be limited to those 
To the extent that there has been any assessment of the role of time in the context of the real risk test, it has focused on the need for a forward-looking assessment from the date of determination. The ECtHR, for example, is explicit that while historical events may shed light on present or future events, ${ }^{57}$ current circumstances are determinative. Often, but not always, this formulation is accompanied by the ECtHR declaring that it makes an ex nunc assessment ('from now on'). For example, in SHHv United Kingdom, it stated:

In order to determine whether there is a real risk of ill-treatment in this case, the Court must examine the foreseeable consequences of sending the applicant to Afghanistan, bearing in mind the general situation there and his personal circumstances ... A full and ex nunc assessment is called for as the situation in a country of destination may change over the course of time. Even though the historical position is of interest insofar as it may shed light on the current situation and its likely evolution, it is the present conditions which are decisive and it is therefore necessary to take into account information that has come to light since the final decision taken by the domestic authorities. ${ }^{58}$

Thus, an ex nunc test requires that the future risk be assessed at the date of the decision-maker's consideration of the case ${ }^{59}$ In other words, procedurally it requires an assessment of future risk today, but it should not foreclose the substantive assessment. As the Grand Chamber of the ECtHR recalled in $J K$ and Others $v$ Sweden, the principle of an ex nunc evaluation of the circumstances requires that the 'assessment must focus on the foreseeable consequences of the applicant's removal to the country of destination in the light of the general situation there and his or her personal circumstances', ${ }^{60}$ The court further explained

\begin{abstract}
that it is assessing the applicants' situation from the present-day point of view. The main question is not how the Swedish immigration authorities assessed the case at the time (that is, when the Migration Agency and the Migration Court took their decisions on 22 November 2011 and 23 April 2012 respectively) but rather whether, in the present-day situation, the applicants would still face a real risk of persecution for the above-mentioned reasons if removed to Iraq. ${ }^{61}$
\end{abstract}

occasions in which the treatment or punishment abroad is certain, imminent and serious': para 83. However, in its reasoning the court emphasized foreseeability not certainty as the test: see para 90.

57 The leading case with this formulation is Chahal (n 28). See also Garayev v Azerbaijan, App No 53688/08, Judgment of 10 June 2010; AGR v Netherlands, App No 13442/08, Judgment of 12 January 2016; AWQ v Netherlands, App No 25077/06, Judgment of 12 January 2016; MRA v Netherlands, App No 46856/07, Judgment of 12 January 2016. The court did not use the language of 'ex nunc' in these cases.

58 SHHv United Kingdom (2013) 57 EHRR 18, para 72. See also Sheekh v Netherlands (2007) 45 EHRR 50; JK v Sweden, App No 59166/12, Judgment of 23 August 2016; Chankayev $v$ Azerbaijan, App No 56688/12, Judgment of 14 November 2013; Tershiyev v Azerbaijan, App No 10226/13, Judgment of 31 July 2014; Mawaka v Netherlands, App No 29031/04, Judgment of 1 June 2010; H v United Kingdom (2013) 57 EHRR 17; EG v United Kingdom (2012) 54 EHRR 1. $\quad{ }^{59}$ Sheekh (n 58) para $136 . \quad 60 J K(\mathrm{n} \mathrm{58)}$ para $83 . \quad 61$ ibid para 113. 
The CJEU, too, undertakes an ex nunc test. In EU law, the assessment of facts and circumstances is regulated by Article 4 of the Qualification Directive. According to the CJEU, this

'assessment' takes place in two separate stages. The first stage concerns
the establishment of factual circumstances which may constitute evidence
that supports the application, while the second stage relates to the legal
appraisal of that evidence, which entails deciding whether, in the light of the
specific facts of a given case, the substantive conditions laid down by Articles
9 and 10 or Article 15 of Directive $2004 / 83$ for the grant of international
protection are met. ${ }^{2}$

More specifically regarding timing, the Qualification Directive provides that the assessment of all relevant facts is to be carried out on an individual basis, as 'at the time of taking a decision on the application'. ${ }^{63}$ This ex nunc assessment of facts and circumstances is further enshrined in the Procedures Directive, which requires that 'Member States shall ensure that an effective remedy provides for a full and ex nunc examination of both facts and points of law, including, where applicable, an examination of the international protection needs pursuant to [the QD (recast)]'.64

One context in which there is explicit reference to a minimum future period is in relation to actors of protection. ${ }^{65}$ Of particular relevance to the present study is the fact that protection from persecution or serious harm under EU law should be 'effective and of a non-temporary nature'. ${ }^{66}$ While there is no finite future period specified, the fact that 'protection' against persecution or serious harm must be non-temporary and durable strongly points to the need for a temporal assessment that looks well beyond the present, or immediate, risk of harm, and into the future. ${ }^{67}$

Having thus established that there is no conceptual reason why imminencein the sense of timing - should be used to limit a State's protection obligations, we now turn to consider how some judicial bodies have nonetheless begun to import this notion into the assessment of international protection claims.

\footnotetext{
62 Case C-277/11 MMv Minister for Justice, Equality and Law Reform, Ireland, Attorney General (First Chamber, 22 November 2012) para 64.

63 Art 4(3)a. See also UNHCR, 'Guidelines on International Protection No 12: Claims for Refugee Status related to Situations of Armed Conflict and Violence under Article 1A(2) of the 1951 Convention and/or 1967 Protocol relating to the Status of Refugees and the Regional Refugee Definitions', UN Doc HCR/GIP/16/12 (2 December 2016) para 24 (Guidelines on International Protection No 12): 'The 1951 Convention protects those who - at the time of the decision - are at risk of persecution in their country of origin, regardless of whether they have already suffered persecution.'

64 European Parliament and Council Directive 2013/32/EU of 26 June 2013 on Common Procedures for Granting and Withdrawing International Protection [2013] OJ L 180/60 art 46.

65 Qualification Directive (n 33) art 7.

66 ibid recital 26, art 7.

67 See also the CJEU interpretation of the cessation clause (Qualification Directive (n 33) art 11 and Refugee Convention art 1C referring to 'durable change' in Joined Cases C-175/08, C-176/08, C-178/08 and C-179/08, Abdulla v Bundesrepublik Deutschland [2010] ECR I-01493.
} 


\section{IV. 'IMMINENCE' IN INTERNATIONAL PROTECTION: THE JURISPRUDENCE OF INTERNATIONAL COURTS AND OVERSIGHT BODIES}

In examining jurisprudence on imminence in international protection, we focused on cases where the notion of imminence was explicitly invoked, or where the court or body used the concept of timing of future harm as a relevant factor in the assessment of the protection claim. ${ }^{68}$

The notion of imminence has been referred to and used explicitly in all jursidictions examined for this research, and, in particular, has been engaged in some cases to reject a claim for international protection. ${ }^{69}$ For example, in at least 18 cases in our study, the ECtHR relied on the absence of an

${ }^{68}$ In the four jurisdictions studied, we identified decisions where imminence was explicitly invoked and where the impact of time was particularly significant. Based on decisions available on the relevant databases at the time of research, we identified 27 cases in relation to UNHRC jurisprudence; 59 cases in relation to UNCAT; 132 cases in relation to the ECtHR; four relevant cases in relation to the CJEU. It may also be noted that the ECtHR has the ability to suspend expulsion or extradition, pursuant to Rule 39 of the court, to prevent an imminent risk of irreparable damage' (Mamatkulov (n 23) para 104). These determinations are not included in this study as there is no factual assessment of imminence. The ECtHR makes such determinations quickly without the full evidence (eg Mamatkulov (n 23); MSS v Belgium and Greece (2011) 53 EHRR 2) and they are not publicly available. Curiously, even though case law indicates that the test for interim measures in practice is 'imminent risk', the Practice Direction on Interim Measures issued by the President of the ECtHR in September 2016 did not refer to this standard, but rather to 'real risk': 'The Court will only issue an interim measure against a Member State where, having reviewed all the relevant information, it considers that the applicant faces a real risk of serious, irreversible harm if the measure is not applied'; ECtHR, 'Practice Direction Interim Measures' (Practice direction issued by the President of the Court in accordance with Rule 32 of the Rules of Court on 5 March 2003 and amended on 16 October 2009 and on 7 July 2011, September 2016), 1.

${ }^{69}$ Khan v Canada, UNHRC, Comm No 1302/2004, UN Doc CCPR/C/87/D/1302/2004 (2006); Singh (Daljit) v Canada, UNHRC, Comm No 1315/2004, UN Doc CCPR/C/86/D/1315/2004 (2006); Minani $v$ Canada, UNCAT, Comm No 331/2007, UN Doc CAT/C/43/D/331/2007 (2009); SPA v Canada, UNCAT, Comm No 282/2005, UN Doc CAT/C/37/D/282/2005 (2006); ET and NT $v$ Switzerland and Italy, App No 79480/13, Decision of 30 May 2017; Ali $v$ Switzerland and Italy, App No 30474/14, Decision of 4 October 2016; MA-M v Finland, App No 32275/15, Decision of 4 October 2016; FM v Denmark, App No 20159/16, Decision of 13 September 2016; NA v Denmark, App No 15636/16, Decision of 28 June 2016; MR v Finland, App No 13630/16, Decision of 24 May 2016; SMH v Netherlands, App No 5868/13, Decision of 13 January 2015; Mohammed Hassan v Netherlands and Italy, App No 40524/10, Decision of 27 August 2013; Miruts Hagos v Netherlands and Italy, App No 9053/10, Decision of 27 August 2013; $J A v$ Netherlands, App No 21459/14, Decision of 3 November 2015; Hussein v Netherlands, App No 27725/10, Decision of 2 April 2013; Diirshi v Netherlands, App No 2314/10, Decision of 10 September 2013; ATH v Netherlands, App No 54000/11, Decision of 17 November 2015; AME v Netherlands, App No 51428/10, Decision of 13 January 2015; Balogun v United Kingdom, App No 60286/09, Judgment of 10 April 2012; Berisha and Haljiti v Former Yugoslav Republic of Macedonia, App No 18670/03, Decision of 16 June 2005; Tomic (n 22) (in relation to a potential violation of art 8 ECHR). In two further judgments, a 'real and imminent' standard was used in dissenting opinions: Tarakhel $v$ Switzerland, App No 29217/12, Judgment of 4 November 2014, partly dissenting opinion of Judges Casadevall, Berro-Lefèvre and Jäderblom (a Dublin transfer case); $N$ v Finland, App No 38885/02, Judgment of 26 July 2005. There, Judge Maruste expressed the view that the applicant's 'risk of possible ill-treatment' in the Democratic Republic of Congo was 'not imminent and real'. 
imminent risk to reject the application. ${ }^{70}$ Although it has not been invoked as a ground for refusal of protection by the CJEU, ${ }^{71}$ that court does recognize considerations of time, seriousness of harm, and likelihood/probability as key elements in the interpretation of EU law relating to protection. ${ }^{72}$

While the number of cases that have invoked the notion in an explicit manner to date is small in the context of the overall caseload of these jurisdictions, it is nonetheless significant that it has been invoked at all, given that it does not appear to have a solid foundation in traditional principles of risk assessment in the law on international protection. Similarly, although some decisionmakers have expressed scepticism about whether the invocation of a standard of 'real and imminent risk' (as has been adopted in a line of ECtHR authority primarily concerning Dublin transfers) is simply a result of 'nice differences of language', ${ }^{73}$ the reality is that it has been used to deny protection-and the danger is that it could be adopted in future cases. This is particularly concerning given the lack of focused discussion about why it is used, and whether there is any principled basis for doing so.

Analysis of the case law from our selected jurisdictions reveals that while supranational courts and international oversight bodies apply certain general principles (eg substantial grounds for believing and real risk), their decisions lack detailed reasoning or information about how near or far in time a risk of future harm needs to be, what type of evidence is required to substantiate it, and why (when explicitly referred to) 'imminence' is used as a test at all, given that it is not expressly contained in any of the relevant legal frameworks.

The analysis below identifies the two key contexts in which these challenges are most acute. The first is where the notion of imminence has been transplanted from a procedural setting (where, arguably, it has an appropriate role to play) to a substantive assessment (where, arguably, it does not). The second concerns

70 In 17 of these cases, the claims were found to be manifestly ill-founded: ET and NT (n 69); Ali (n 69); MA-M (n 69); FM (n 69); NA (n 69); MR (n 69); SMH (n 69);JA (n 69); Hussein (n 69); Diirshi (n 69); ATH (n 69); AME (n 69); Mohammed Hassan (n 69); Miruts Hagos (n 69) (all involving transfer back to Italy pursuant to the Dublin Regulation); Balogun (n 69); Berisha and Haljiti (n 69); Tomic (n 22). While in Kaboulov v Ukraine, App No 41015/04, Judgment of 19 November 2009, the applicant succeeded in showing a general risk of treatment in violation of art 3, the ECtHR applied a 'real and imminent risk' standard in rejecting the more personal risk faced by the applicant: para 112 .

71 The CJEU has so far ruled in 14 cases of interpretation of the Qualification Directive (four more cases are pending); one such case was decided under the Returns Directive instead of the Qualification Directive (Case C-562/13 Centre public d'action sociale d'Ottignies-Louvain-laNeuve v Abdida (Grand Chamber, 18 December 2014) (Abdida). For a full list of these cases, see International Association of Refugee Law Judges (European Chapter), 'An Introduction to the Common European Asylum System for Courts and Tribunals - A Judicial Analysis' (European Asylum Support Office 2016) 44-6. It may also be noted that although CJEU judgments so far relate to the original Qualification Directive of 2004, these are nevertheless relevant to the interpretation of the recast Qualification Directive of 2011, particularly since the provisions relating to persecution and serious harm remained unchanged.

72 The most explicit discussion of imminence is found in the recent decision in Case C-353/16 MP v Secretary of State for the Home Department (Grand Chamber, 24 April 2018) paras 36-45.

73 NA (Sudan) v the Secretary of State for the Home Department [2016] EWCA Civ 1060, para 74. 
protection claims involving a risk of harm that may manifest in the medium- or long-term, such as medical cases where a person's health may decline over a period of time and environmental deterioration linked to the impacts of climate change. Such cases inevitably raise policy considerations about the role of the receiving State in contributing to/mitigating adverse impacts, and the responsibility of the host State to protect people from potential (but perhaps mitigable) harm.

\section{A. Imminence: The Dangers of Transplantation from Procedural to Substantive Issues}

The context in which the notion of imminence is most likely to be invoked explicitly is in assessing whether an applicant has met procedural requirements related to standing or 'victimhood'. This is particularly pronounced in the international and regional adjudicatory human rights bodies where a complainant must establish that he or she has standing to bring a complaint. ${ }^{74}$

For example, Article 1 of the ICCPR's First Optional Protocol provides that the UNHRC can consider complaints from individuals 'who claim to be victims of a violation by that State Party of any of the rights set forth in the Covenant'. ${ }^{75}$ Article 2 further provides that 'individuals who claim that any of their rights enumerated in the Covenant have been violated and who have exhausted all available domestic remedies may submit a written communication to the Committee for consideration'. Where a complainant does not meet the criteria of a 'victim', the claim is deemed inadmissible. ${ }^{76}$

The UNHRC has long taken the view that an individual can only claim to be a victim of a violation 'if he or she is actually affected'. ${ }^{77}$ In 1993, it introduced a further gloss on this test by stating that to be a victim, a person 'must show either that an act or an omission of a State party has already adversely affected his or her enjoyment of such right, or that such an effect is imminent' ${ }^{78}$ In that case,

74 This is described in various ways, including in the ICCPR, CAT and ECHR context as whether or not the person is a 'victim'. It may be noted that this is not the case under refugee law.

75 See also ECHR art 34 and CAT art 22(1).

76 In the context of the ECHR, see Bahaddar v Netherlands (1998) 26 EHRR 278, where the ECtHR found the applicant not to be at risk of imminent removal and therefore was 'in no imminent danger of treatment contrary to Article 3': para 47. See also, eg, Babajanov v Turkey, App No 49867/ 08, Judgment of 10 May 2016, where the court held at para 81 that the applicant could not be 'considered to be a victim within the meaning of Article 34' of the ECHR in relation to feared deportation from Turkey; $M E v$ Sweden, App No 71398/12, Judgment of 8 April 2015 para 35; $A G v$ Sweden, App No 22107/08, Decision of 6 December 2011, where the applications were struck out due to the grant of permanent residence permits, thus resolving the matters. In each of these cases, there was no longer an 'imminent risk' of removal.

77 Aumeeruddy-Cziffra v Mauritius, UNHRC, Comm No 35/1978, UN Doc CCPR/C/OP/1 (1984) para 9.2; see also EP v Colombia, UNHRC, Comm No 318/1988, UN Doc CCPR/C/39/ $\mathrm{D} / 318 / 1988$ (1990) para 8.2.

${ }^{78}$ EW v Netherlands, UNHRC, Comm No 429/1990, UN Doc CCPR/C/47/D/429/1990 (1993) para 6.4 (emphasis added). 
the UNHRC was not persuaded that, 'at the relevant period of time', the continuing deployment of nuclear weapons in the Netherlands placed the authors - a group of 6,588 concerned Dutch citizens - in the position of 'victims'. 79

The same approach was adopted in the 2006 decision of Aalbersberg $v$ Netherlands, which involved a group of 2,085 Dutch citizens who claimed a violation of Article 6 (the right to life) by virtue of the Netherlands' willingness to use nuclear weapons and to 'cooperate with such use'. ${ }^{80}$ The UNHRC framed the question of standing in terms of whether 'the State's stance on the use of nuclear weapons presented the authors with an existing or imminent violation of their right to life' ${ }^{81}$ No such case was made out and the UNHRC therefore dismissed the claim as inadmissible. ${ }^{82}$

The rationale for the use of imminence in relation to standing is manifestly clear: the international and regional adjudicatory bodies do not have the power to issue advisory opinions or engage in moot adjudications. ${ }^{83}$ Further, and perhaps more importantly, where a person is not currently a 'victim' for jurisdictional purposes, it is of course possible that the circumstances may change and hence permit a subsequent application to be made once exposure to harm is, indeed, imminent. This was explicitly acknowledged in an analogous context in $H v$ Norway, where the ECtHR struck out the claim but nonetheless reassured the applicant that 'should her legal situation in Norway change and a risk of expulsion become imminent, it remain[ed] open to her to lodge a new application with the Court', which could include 'a request for an interim measure'. ${ }^{84}$

However, while the notion of imminence may be justified in the limited context of admissibility, our analysis reveals that there is sometimes a conflation of two conceptually distinct issues: the question of standing/victimhood, and the substantive question of the human rights violation. In the latter context, assuming that there is an imminent risk of removal, extradition, deportation, or expulsion, the assessment of State responsibility - and hence of likely future harm-must be undertaken at that moment and cannot be deferred to a later

79 ibid.

${ }^{80}$ Aalbersberg v Netherlands, UNHRC, Comm No 1440/2005, UN Doc CCPR/C/87/D/1440/ 2005 (2006) para 3.4.

81 ibid para 6.3 .

82 ibid para 7. By contrast, the UNCAT found that where an expulsion order was in force against a complainant, the possibility that the complainant could potentially be granted a residence permit in the future was not sufficient to meet the State's obligation under art 3: AD v Netherlands, UNCAT, Comm No 96/1997, UN Doc CAT/C/23/D/96/1997 (1999) paras 6.2, 7.3.

${ }_{83}$ An exception is the ECtHR, with Protocol 16 now allowing the highest courts and tribunals of a State Party to request the court to give advisory opinions on questions of principle relating to the interpretation or application of the rights and freedoms defined in the Convention or the protocols thereto: Human Rights (Protocol No 16), 2.X.2013, ETS 214, entered into force on 1 August 2018.

${ }^{84}$ See $H v$ Norway, App No 51666/13, Decision of 17 February 2015 P, para 8 . See also, eg, Babajanov (n 76), para 80; Sijaku v Former Yugoslav Republic of Macedonia, App No 8200/02, Decision of 27 January 2005, where the court considered that the applicant could make a new application at a later stage because the applicant's potential return 'would take place at an unspecified future time' and the circumstances in the home country and 'the elements of risk on which the applicant now relies' may be significantly different. 
time when the evidence is clearer or more compelling. As long as the removal is imminent - and thus the person's standing or 'victimhood' is made out - the substantive question turns on the likelihood of harm resulting from such removal, and arguably not on precisely how soon after removal it may manifest. To conflate these two fundamentally different contexts and issues, especially without explanation as to the justification for doing so, ${ }^{85}$ is highly problematic.

For example, just two weeks after its decision in Aalbersberg, the UNHRC conflated these separate issues by finding a claim to be inadmissible because, inter alia, the applicant had not adduced sufficient evidence in support of his contention that he would be 'exposed to a real and imminent risk of violations of articles 6 and 7 of the Covenant if deported to Pakistan'.86 Similarly, in another largely contemporaneous decision, the UNHRC found a claim to be inadmissible, in part because the complainant had failed to adduce sufficient evidence that he would be 'exposed to a real and imminent risk of violations of articles 6 and 7 of the Covenant'. ${ }^{87}$ In these admissibility decisions, the UNHRC apparently applied the notion of imminence-from a test for standing - to the substantive consideration of the alleged violations.

Similarly, in Europe, the ECtHR has held that even where all the formal admissibility conditions have been met, it "may nevertheless declare [an application] inadmissible for reasons relating to the examination on the merits' ${ }^{88}$ For instance, in a number of decisions involving Dublin transfers of asylum seekers from one EU Member State to another, the ECtHR has found that it has not been 'demonstrated' or 'established' that an applicant's 'future prospects if returned ..., whether taken from a material, physical or psychological perspective, disclose a sufficiently real and imminent risk of hardship severe enough to fall within the scope of Article 3' of the ECHR. ${ }^{89}$ In reaching these decisions, at times the court curiously relied on its reasoning in cases such as Ireland $v$ United Kingdom ${ }^{90}$ and Jalloh $v$

\footnotetext{
${ }^{85}$ It may nevertheless be explained by the fact that human rights instruments are essentially concerned with protection against refoulement. However, the well-founded fear test in international refugee law requires the decision-maker to make an assessment on the predicament of an individual irrespective of whether return to the country of nationality or former habitual residence is a viable or imminent option. Indeed, the very wording of art $1 \mathrm{~A}(2)$ of the Refugee Convention requires the applicant to be 'unable ... to return' to their country of origin. See eg Refugee Appeal No 74880 [2005] NZRSAA 294, para 70; Refugee Appeal No 73861 [2005] NZRSAA 228, para 78. See also Hathaway and Foster (n 45) 69, 70.

${ }^{86}$ Khan (n 69) para 5.4.

87 Singh (n 69) which is actually prior to Aalbersberg but very contemporaneous: see para 6.3.

88 ECtHR, 'Practical Guide on Admissibility Criteria' (2018) para 252. This Guide is available for downloading at <www.echr.coe.int $>$ (Case-law - Case-law analysis - Admissibility guide).

${ }^{89}$ Hussein (n 69) para 78 (emphasis added); Diirshi (n 69) para 139. See also, for the same formulation, $A M E$ (n 69) para 36; JA (n 69) para 32; $A T H$ (n 69) para 41. ET and NT (n 69) para 27; Ali (n 69) para 35; MA-M (n 69) para 28; FM (n 69) para 29; $N A$ (n 69) para 32; $M R$ (n 69) para 29; SMH (n 69) para 51; Mohammed Hassan (n 69) para 176; Miruts Hagos (n 69) para 38.

90 Ireland $v$ United Kingdom [1978] 2 EHRR 25, para 161.
} 
Germany, ${ }^{91}$ neither of which referred to 'real and imminent risk'. The rationale for introducing an imminence test has not, therefore, been articulated or justified.

\section{B. Imminence and Slow-Onset Harm: Particular Challenges}

The timing of future harm is relevant in a range of factual contexts, but the two areas in which the issue is most likely to be raised in contemporary jurisprudence are risks associated with deteriorating health on return to the country of origin, and those associated with the impacts of climate change in the country of origin.

Returning to the departure point for our inquiry, the key challenge is whether it is possible or appropriate to identify a basis on which an international protection application can be rejected if the harm feared by the applicant is likely to manifest over the longer term. Is there (and should there be) a principled way of defining the relevant time period in assessing risk of future harm? How would variables such as the potential mitigating impacts of disaster risk reduction measures be accommodated within the analysis? As standard refugee cases show, context is extremely important and the rules cannot be too prescriptive: the focus is not on certainty of harm, but whether there is a real risk of it. ${ }^{92}$

By way of analogy, in situations relating to generalized violence, decisionmakers must carry out a detailed analysis of all possible factors and consequences, including potential risk-mitigating factors and their attendant effects. As UNHCR's Guidelines on International Protection No 12 (UNHCR's Guidelines) relating to situations of armed conflict and violence note:

When assessing the risk, it is important to take into account the fluctuating character of many contemporary situations of armed conflict and violence. ... For example, even if the level of violence at the time of decision-making is relatively low, over time the situation of armed conflict and violence may change, increasing the degree of risk establishing a well-founded fear. ... Similarly, even if violence has not yet broken out in a particular part of the country, it may be foreseeable that the violence will spread there, taking into account the overall context and history of the situation of armed conflict and violence, the trajectory and mapping of the violence, the power dynamics at play and other conditions in the applicant's country of origin. The effects of past violence may also still rise to the level of persecution, despite a temporary

91 Jalloh v Germany, App No 54810/00, Judgment of 11 July 2006, para 67. Current and previous versions of the ECtHR's 'Practical Guide on Admissibility' do not cite an imminence standard in relation to admissibility decisions, see 2011, 2014 and 2018 versions.

92 See eg UNHCR, Guidelines on International Protection No 12 (n 63) para 21 (footnote omitted): 'This does not require a probability calculus, based, for example, on the number of people killed, injured or displaced, but requires an analysis of both quantitative and qualitative information assessed against the applicant's circumstances.' 
suspension of hostilities, and need to be assessed carefully. In addition, the implementation of peace and demobilization agreements may lead to new armed actors filling vacuums of power, or to the consolidation of groups composed of former members who have not disarmed and reintegrated into society. This also requires a detailed analysis that constantly evolves in response to local developments in the country of origin. ${ }^{93}$

Furthermore, the 'long-term consequences' of armed conflict or violence, 'such as demolition of vital infrastructure, insecurity and abject poverty', ${ }^{94}$ can amount to persecution or serious harm, while

[t]he systematic denial of food and medical supplies, the cutting of water supplies and electricity, the destruction of property or the militarization or closure of hospitals and schools may also constitute serious human rights or IHL violations that affect whole communities. ${ }^{95}$

UNHCR's Guidelines are very useful in highlighting multi-causal movements, the unpredictable nature of armed conflict, its frequently shifting patterns over time, and the long-term consequences of conflict. Notably they do not purport to explain where to draw the line in relation to future harm precisely because this is not a decisive factor. Rather, they state that decision-makers should look at the trajectory of harm (violence, in that context) in deciding whether it is 'foreseeable' that it will spread into an area where there is no sign of violence at the time of the risk assessment. ${ }^{96}$ The focus of the assessment remains on foreseeability of harm, and the Guidelines suggest factors to guide that assessment. They highlight that even where mitigating measures might intervene (such as the implementation of peace and demobilization agreements), there may still be negative outcomes. In other words, the presence of 'multiple' possibilities, each of which involves speculation, does not foreclose the possibility that protection is warranted. Rather, the flexibility and open-ended nature of the well-founded fear and real risk tests provides the necessary framework for decision-makers to assess protection claims.

Against this backdrop, we now turn to two contexts in which these issues have arisen, namely health deterioration and movement in the context of the adverse impacts of climate change.

\section{Health deterioration}

The context in which the question of imminence of harm has arisen most squarely to date concerns cases involving deterioration of health after removal. The most developed jurisprudence on this issue emanates from the

\footnotetext{
93 ibid para 25.

94 ibid para 19.

95 ibid para 18. See H Lambert and T Farrell, 'The Changing Character of Armed Conflict and the Implications for Refugee Protection Jurisprudence’ (2010) 22 IJRL 237.

96 UNHCR, Guidelines on International Protection No 12 (n 63) para 25.
} 
ECtHR. Its case law spans decades but has not developed consistently. ${ }^{97}$ In the seminal decision of $D v$ United Kingdom in 1997, the court held that the proposed removal of a citizen of St Kitts from the United Kingdom in the 'advanced stages of a terminal and incurable illness' 98 would amount to a violation of Article 3 of the ECHR on the basis that:

The abrupt withdrawal of these facilities will entail the most dramatic consequences for him. It is not disputed that his removal will hasten his death. There is a serious danger that the conditions of adversity which await him in St Kitts will further reduce his already limited life expectancy and subject him to acute mental and physical suffering. ${ }^{99}$

While imminence of harm was not an explicit consideration in that case, it was central (albeit implicit) in a subsequent decision in 2008, namely $N v$ United Kingdom. There, the court rejected an analogous claim on the basis that:

the quality of the applicant's life, and her life expectancy, would be affected if she were returned to Uganda. The applicant is not, however, at the present time critically ill. The rapidity of the deterioration which she would suffer and the extent to which she would be able to obtain access to medical treatment, support and care, including help from relatives, must involve a certain degree of speculation, particularly in view of the constantly evolving situation as regards the treatment of HIV and AIDS worldwide. ${ }^{100}$

This decision had the effect of precluding successful claims by applicants seeking to resist removal due to health-related issues. ${ }^{101}$ However, in the 2016 judgment of Paposhvili v Belgium, the ECtHR adopted a less rigid approach. In that case, the Grand Chamber accepted a longer time frame for the risk assessment, noting that 'the impact of removal on the person

97 C Costello, 'The Search for the Outer Edges of Non-refoulement in Europe: Exceptionality and Flagrant Breaches' in B Burson and DJ Cantor (eds), Human Rights and the Refugee Definition: Comparative Legal Practice and Theory (Brill 2016).

98 D v United Kingdom (1997) 24 EHRR 423, para 51. $\quad 99$ ibid para 52.

$100 N v$ United Kingdom (2008) 47 EHRR 39, para 50 (emphasis added). $N$ was followed by the CJEU in Case C-542/13 M'Bodj v État belge (Grand Chamber, 18 December 2014), and in Abdida (n 71).

101 Yoh-Ekale Mwanje v Belgium, App No 10486/10, Judgment of 20 December 2011. In Bensaid v United Kingdom (2001) 33 EHRR 10, para 39: 'The Court finds that the risk that the applicant would suffer a deterioration in his condition if he is returned to Algeria and that, if he did, he would not receive adequate support or care is to a large extent speculative.' Similarly, see $A S v$ Switzerland, App No 39350/13, Judgment of 30 June 2015, para 36. In other cases, the court has rejected or found claims inadmissible because the applicant did not meet the 'exceptional circumstances' threshold set out in $D$ (n 98), namely that he or she was not critically ill at the time of the determination. See eg Ndangoya $v$ Sweden, App No 17868/03, Decision of 22 June 2004; Kochieva v Sweden, App No 75203/12, Decision of 30 April 2013; Arcila Henao v Netherlands, App No 13669/03, Decision of 24 June 2003; Amegnigan v Netherlands, App No 25629/04, Decision of 25 November 2004; EO v Italy, App No 34724/10, Decision of 10 May 2012; Karara v Finland, App No 40900/98, Decision of the Commission, 29 May 1998. In Balogun (n 69), the court considered the applicant's risk of suicide on return to Nigeria, and, in finding the claim manifestly ill-founded, referred to the lack of 'real and imminent risk'. 
concerned must be assessed by comparing his or her state of health prior to removal and how it would evolve after transfer to the receiving State.'102 Nevertheless, the applicant must still be 'seriously ill' at the time of removal, and while

not at imminent risk of dying, would [nevertheless] face a real risk, on account of the absence of appropriate treatment in the receiving country or the lack of access to such treatment, of being exposed to a serious, rapid and irreversible decline in his or her state of health resulting in intense suffering or to a significant reduction in life expectancy. ${ }^{103}$

This is reminiscent of the language employed by the CJEU in the 2014 Abdida decision in which the court referred to 'the seriousness and irreparable nature of the harm that may be caused by the removal', namely 'a serious risk of grave and irreversible deterioration in his state of health'. ${ }^{104}$ More recently, the CJEU has considered this issue in some depth, citing the test adopted by the ECtHR in Paposhvili; namely, 'a serious, rapid and irreversible decline in his state of health'. ${ }^{105}$ The CJEU concluded that in assessing the obligation of nonrefoulement in Article 4 of the Charter of Fundamental Rights of the European Union, return is not permitted 'where such removal would result in a real and demonstrable risk of significant and permanent deterioration in the state of health of the person concerned'. ${ }^{106}$ The use of the word 'deterioration' by the CJEU appears to imply that an applicant's medical condition need not be at a critical stage at the time of the decision.

The concession in Paposhvili that a decision-maker must consider the evolving situation post-transfer is significant, although there is no precise framing of the outer limits of the relevant temporal period. However, it clearly allows for a longer-term assessment than the more limited test articulated in $N v$ United Kingdom. This is certainly how Paposhvili has been

102 Paposhviliv Belgium App No 41738/10, Judgment of 13 December 2016, para 188 (emphasis added). The court has since discussed Paposhvili on one occasion in $H v$ Switzerland, App No 67981/16, Decision of 15 May 2018, finding the application inadmissible on the merits because 'the second applicant's HIV is not at an advanced stage and...her state of health is not such as to bar her transfer to Italy in accordance with the criteria set out in the case of Paposhvili v Belgium...'.

103 ibid para 183 (emphasis added). Compare also with Aswat $v$ United Kingdom (2014) 58 EHRR 1, where the court found that extradition would violate art 3 despite a complete lack of certainty about which type of institution and the conditions the applicant would be in. See also, the Dissenting Opinion of Tulkens, Bonello, and Spielmann JJ in N (n 100) para 23.

${ }_{104}$ Abdida (n 71) paras 50, 53. ${ }_{105} M P(\mathrm{n} \mathrm{72)}$ para 40.

106 ibid. para 40. However, in relation to granting subsidiary protection, in order to meet the definition in art 15(b) of the Qualification Directive, there must be an intentional deprivation of medical care, see para 51: 'In that respect, it should be recalled that the court has held that the serious harm referred to in Article 15(b) of Directive 2004/83 cannot simply be the result of general shortcomings in the health system of the country of origin. The risk of deterioration in the health of a third country national who is suffering from a serious illness, as a result of there being no appropriate treatment in his country of origin, is not sufficient, unless that third country national is intentionally deprived of health care, to warrant that person being granted subsidiary protection.' 
understood by the English Court of Appeal, which recently affirmed that 'it is clear' that the case 'relaxes the test for violation of Article 3 in the case of removal of a foreign national with a medical condition', but that 'it does so only to a very modest extent'. ${ }^{107}$ The Court of Appeal's interpretation assumes that imminence is still a requirement; it has merely been extended from 'imminence of death' 108 as the criterion to 'a real risk of a serious and rapid decline in ... health resulting either in intense suffering (to the Article 3 standard) or death in the near future' ${ }^{109}$

The Paposhvili decision is consistent with an analogous 2015 decision of the UNHRC. There, Canada was found to be in violation of Article 7 of the ICCPR for deporting a mentally ill person to Jamaica, notwithstanding Canada's arguments that the potential longer-term consequences of deportation were 'mere conjecture' and 'mere speculation' because it was 'just as likely' that the situation would not be as dire as predicted. ${ }^{110}$ On the other hand, in a case where there was no evidence of the applicant's health deteriorating on the available evidence at the time of the determination, yet arguably a longer-term risk of death in the DRC, UNCAT found this aspect of the claim inadmissible. ${ }^{111}$

In sum, the health context suggests that while the jurisprudence has become more open to the assessment of a claim within a longer time frame, the notion of imminence, in the sense of timing, is still a present and limiting factor that influences the scope of States' obligations to provide international protection.

\section{Climate change}

The other key context in which the question of timing of harm arises concerns claims linked to the adverse impacts of climate change. While the jurisprudence is far less developed than in the health context, such claims are ripe for future litigation and therefore warrant analysis.

The most comprehensive consideration of the future impacts of climate change in the protection context has been undertaken by decision-makers in New Zealand. ${ }^{112}$ While the notion of 'imminence' has been invoked explicitly in such cases (based on the UNHRC cases on standing), ${ }^{113}$ the

\footnotetext{
107 AM (Zimbabwe) \& Anor $v$ The Secretary of State for the Home Department [2018] EWCA Civ 64, para 37. $\quad{ }_{108}$ ibid para 38. $\quad{ }^{109}$ ibid para 44. (emphasis added).

110 AHG v Canada, UNHRC, Comm No 2091/2011, UN Doc CCPR/C/113/D/2091/2011 (2015) paras 4.5, 5.4, 6.3.

111 Njamba v Sweden, UNCAT, Comm No 322/2007, UN Doc CAT/C/44/D/322/2007 (2010) para 7.3. This claim was also found inadmissible because, consistently with UNCAT's jurisprudence, 'the aggravation of the condition of an individual's physical or mental health by virtue of a deportation is generally insufficient, in the absence of additional factors, to amount to degrading treatment in violation of article 16'.

$112 * A C$ (Tuvalu) (n 10); AF (Kiribati) (n 10); AF (Tuvalu) (n 10); *BG (Fiji) (n 10); Teitiota (HC, n 10); Teitiota (CA, n 10); Teitiota (SC, n 10); Burson (n 1).

${ }^{113}$ EW (n 78); Aalbersberg (n 80).
} 
Tribunal has observed that "[i]mminence should not be understood as imposing a test which requires the risk to life be something which is, at least, likely to occur'. ${ }^{114}$ Rather, it is comparable to the well-founded fear test in refugee law, requiring 'no more than sufficient evidence to establish substantial grounds for believing the appellant would be in danger'. ${ }^{115}$ However, it is important to note that the Tribunal found that the forward-looking nature of the protection inquiry demands that disaster risk reduction and adaptation strategies be taken into account in assessing future risks. ${ }^{116}$ As subsequently expressed by a member of the tribunal in an extra-curial capacity, the longer the future time frame, the less predictive certainty there is and the more speculative the risk assessment becomes because of the potential for mitigation, adaptation, and other risk-reducing actions. ${ }^{117}$ Accordingly, in the cases considered to date, the climate-change-related harms were assessed as being insufficiently 'present', or the applicants not 'in danger', in part due to the potential for intervening adaptive measures. ${ }^{118}$ This conclusion is debatable given that, as recognized in the UNHCR Guidelines related to armed conflict and violence, the possibility of multiple potential outcomes does not automatically overcome the need for international protection, particularly when the trajectory of harm is moving in a clear direction.

In this regard, it is instructive to consider assessments by the Intergovernmental Panel on Climate Change (IPCC) of the likelihood of certain future climate change risks (which could affect displacement). The findings listed below are based on the IPCC's evaluation of the underlying scientific evidence and the degree of expert agreement, the combination of which determines the level of 'confidence' ascribed (ranging from 'very low' to 'very high'). ${ }^{119}$ The term 'virtually certain' (in the last bullet point) means that the probability is $99-100$ per cent. ${ }^{120}$ According to the IPCC:

- Impacts from recent climate-related extremes, such as heat waves, droughts, floods, cyclones, and wildfires, show the significant vulnerability and exposure of many human systems to current climate variability (very high confidence). ${ }^{121}$

114 AF (Kiribati) (n 10) para 90.

115 ibid; see also *AC (Tuvalu) (n 10) para 57. This was notwithstanding his recognition, in subsequent remarks given in a personal capacity, that in other areas of international law, such as self-defence, 'imminence' seems to envisage a very immediate time frame for harm to materialize, and certainly more immediate than the real chance standard in refugee law: Burson (n 1) $7 . \quad 116$ See eg *AC (Tuvalu) (n 10) para 69; AF (Kiribati) (n 10) para 88.

117 Burson (n 1) 8-10.

$118 A F$ (Kiribati) (n 10) para 89; *AC (Tuvalu) (n 10) paras 58, 102, 109. This could include disaster risk reduction and climate change adaptation measures, among other things.

119 Intergovernmental Panel on Climate Change (IPCC) (Core Writing Team, RK Pachauri and L Meyer (eds)), Climate Change 2014: Synthesis Report (IPCC 2014) 121: Confidence in the 'validity of a finding [is] based on the type, amount, quality, and consistency of evidence (eg mechanistic understanding, theory, data, models, expert judgment) and on the degree of agreement.'

120 ibid 2.

121 ibid 8. 
- It is very likely that heat waves will occur more often and last longer, and that extreme precipitation events will become more intense and frequent in many regions. The ocean will continue to warm and acidify, and global mean sea level will rise. ${ }^{122}$

- Low-lying areas are at risk from sea-level rise, which will continue for centuries even if global mean temperature is stabilized (high confidence). ${ }^{123}$

- It is virtually certain that global mean sea-level rise will continue for many centuries beyond 2100 (the amount will depend on future emissions). ${ }^{124}$

- Over the course of the twenty-first century, climate change is expected to lead to increases in ill-health in many regions, especially in developing countries with low incomes (high confidence). ${ }^{125}$

- The negative impacts of climate change on crop yields, across a wide range of regions and crops, have been more common than positive impacts (high confidence). ${ }^{126}$

- Climate change is projected to increase risks in urban areas for people, assets, economies and ecosystems, including from heat stress, storms and extreme precipitation, inland and coastal flooding, landslides, air pollution, drought, water scarcity, sea level rise and storm surges (very high confidence). 'These risks are amplified for those lacking essential infrastructure and services or living in exposed areas.' 127

The high degree of likelihood expressed in each finding above would certainly meet the well-founded fear threshold in refugee law. ${ }^{128}$ As discussed above in Part III, it is not disputed that a 'well-founded fear' of being persecuted can equate to a less than 50 per cent chance of harm (even as low as 10 per cent) if the risk is plausible and reasonable. ${ }^{129}$ Speculation about what 'might' happen in the future is thus a central component of determining refugee status. ${ }^{130}$ However, decision-makers place limits on how pre-emptive flight

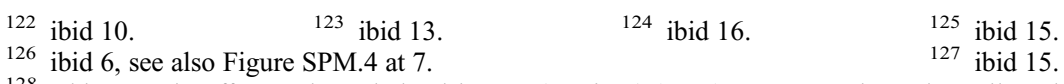

128 This was, in effect, acknowledged in $A F$ (Kiribati) (n 10) para 90, where the Tribunal observed that "the concept of an "imminent" risk to life ... requires no more than sufficient evidence to establish substantial grounds for believing the appellant would be in danger. In other words, these standards should be seen as largely synonymous requiring something akin to the refugee "real chance" standard. That is to say, something which is more than above mere speculation and conjecture, but sitting below the civil balance of probability standard.'

129 Chan v Minister for Immigration and Ethnic Affairs (1989) 169 CLR 379, 429 (McHugh J), citing Cardoza-Fonseca (n 49); Refugee Appeal No 71404/99 [1999] NZRSAA 292, paras 26-27. The UNHCR 'Handbook on Procedures and Criteria for Determining Refugee Status under the 1951 Convention and the 1967 Protocol relating to the Status of Refugees', UN Doc HCR/IP/4/Eng/Rev.1 (1992) para 42, states: 'In general, the applicant's fear should be considered well-founded if he can establish, to a reasonable degree, that his continued stay in his country of origin has become intolerable to him for the reasons stated in the definition, or would for the same reasons be intolerable if he returned there.' See also A Grahl-Madsen, The Status of Refugees in International Law (Leyden 1966) vol 1, 181.

${ }^{130}$ Goodwin-Gill and McAdam (n 44) 54. 
must be to warrant protection, which differ depending on the particular individual's circumstances and turn on 'the relation between the nature of the persecution feared and the degree of likelihood of its happening'. ${ }^{131}$ The assessment of the intensity, severity, and nature of future harm, based on its foreseeability in light of the individual's circumstances, is the crucial factor. ${ }^{132}$

The IPCC has noted that '[t]ransformations in economic, social, technological and political decisions and actions can enhance adaptation and promote sustainable development (high confidence)', 133 and '[i]nnovation and investments in environmentally sound infrastructure and technologies can reduce GHG [greenhouse gas] emissions and enhance resilience to climate change (very high confidence).' ${ }^{134}$ However, in the context of a protection claim, the future mitigation/adaptation possibilities remain speculative and uncertain, and do not detract from the current trajectory of adverse climate change impacts. The competing possibilities thus need to be evaluated in light of the less demanding standard of proof applied in refugee and human rights law.

In conclusion, while the climate change context presents particular challenges, the assessment of an applicant's need for international protection should rest on uniform principles of refugee and human rights law, albeit with sufficient flexibility to respond to different factual contexts.

The two examples discussed above highlight the difficulty of identifying a precise time frame to assess potential future harm. Indeed, it is likely impossible and inappropriate to attempt to devise with any precision a time frame that delimits the scope of inquiry. After all it is not clear why State responsibility for future human rights violations following removal should be limited to those occurring within an immediate or short-term period.

\section{DOES IMMINENCE HAVE ANY PLACE IN INTERNATIONAL PROTECTION?}

As mentioned above, there is little discussion in the case law as to the rationale and justification for invoking an imminence assessment. However, one notable issue that has emerged from a close reading of the case law for this article is that, although 'well-founded fear' has generally not been overlaid with the additional gloss of necessity, directness, or even foreseeability, these concepts are prevalent in the jurisprudence on 'real risk'. Indeed, it appears that it is the introduction of additional factors by some supranational courts and other international oversight bodies, such as 'necessary and foreseeable', ${ }^{135}$ which has sometimes resulted in an

131 ibid 64.

132 See eg M Foster, International Refugee Law and Socio-Economic Rights: Refuge from Deprivation (Cambridge University Press 2009) 192-3.

133 IPCC (n 119) 20 (emphasis omitted). 134 ibid 26 (emphasis omitted).

135 See eg ARJ v Australia, UNHRC, Comm No 692/1996, UN Doc CCPR/C/60/D/692/1996 (1997) para 6.8 (emphasis added). 
imminence-like assessment. Where courts invoke a foreseeability test alone, imminence does not appear to be relevant. But where the concept of necessity (or similar) is introduced, if the risk is not imminent then it seems difficult for decision-makers to conclude that a necessary consequence of removal is the violation of human rights. ${ }^{136}$

The problem is that 'necessary' and 'foreseeable' are conceptually distinct, and it is not clear where the necessity test originated or what its principled basis could be. To take the jurisprudence of the UNHRC as an example, General Comment 31 sets out the basis for an implied non-refoulement obligation, stating that:

Moreover, the article 2 obligation requiring that States Parties respect and ensure the Covenant rights for all persons in their territory and all persons under their control entails an obligation not to extradite, deport, expel or otherwise remove a person from their territory, where there are substantial grounds for believing that there is a real risk of irreparable harm, such as that contemplated by articles 6 and 7 of the Covenant, either in the country to which removal is to be effected or in any country to which the person may subsequently be removed. The relevant judicial and administrative authorities should be made aware of the need to ensure compliance with the Covenant obligations in such matters. ${ }^{137}$

There is no mention of 'necessity' in this context, yet from the 1990s onwards, the UNHRC has sometimes described the relevant test as whether, 'as a necessary and foreseeable consequence of deportation', there will be a violation. ${ }^{138}$ The jurisprudence is inconsistent, however, and our analysis has revealed that where foreseeability is the test, a claim is more likely to succeed. ${ }^{139}$ By contrast, when additional factors such as whether the harm

136 See eg Singh (n 69) para 6.3.

137 UN Human Rights Committee (UNHRC), 'General Comment 31: The Nature of the General Legal Obligation Imposed on States Parties to the Covenant', UN Doc CCPR/C/21/Rev.1/Add.13 (26 May 2004) para 12 (General Comment 31).

138 ARJ (n 135) para 6.14 (emphasis added). See also Khan (n 69) para 5.4 and Singh (n 69) para 6.3 for explicit use of a necessary and foreseeable test as well as an imminence standard (discussed above); T v Australia, UNHRC, Comm No 706/1996, UN Doc CCPR/C/61/D/706/1996 (1997) paras 8.4, 8.6; Hamida v Canada, UNHRC, Comm No 1544/2007, UN Doc CCPR/C/98/DR/ $1544 / 2007 /$ Rev.2 (2007), where the UNHRC stated the rule as being whether there is a 'real risk of treatment contrary to article 7 as a necessary and foreseeable consequence of his expulsion ...' para 8.7.

${ }^{139}$ In many cases, the UNHRC simply cites the General Comment 31 provision and does not embellish with a further test of foreseeability and necessity-see eg Choudhary v Canada, UNHRC, Comm No 1898/2009, UN Doc CCPR/C/109/D/1898/2009 (2013) para 9.2. See also $K$ v Denmark, UNHRC, Comm No 2393/2014, UN Doc CCPR/C/114/D/2393/2014 (2015) para 7.3; Khakdar v Russian Federation, UNHRC, Comm No 2126/2011, UN Doc CCPR/C/112/D/2126/ 2011 (2014) para 11.3. In NS v Russian Federation, UNHRC, Comm No 2192/2012, UN Doc CCPR/C/113/D/2192/2012 (2015) the UNHRC adopted this test: whether he would face a 'real, foreseeable and personal risk of being subjected to torture if returned': para 10.4. In Osayi OmoAmenaghawon v Denmark, UNHRC, Comm No 2288/2013, UN Doc CCPR/C/114/D/2288/2013 (2015), the UNHRC adopted the test from General Comment 31 and added that the risk must be personal and that "there is a high threshold for providing substantial grounds to establish that a 
would be a 'necessary' consequence of removal are introduced, the claim is more likely to be rejected.

A good illustration of the issue is provided by $N g v$ Canada. That case concerned a man facing execution on return to the United States, and the UNHRC found that, with respect to the potential method of execution, the sending State could 'reasonably foresee that $\mathrm{Mr} \mathrm{Ng}$, if sentenced to death, would be executed in a way that amounts to a violation' of Article 7 of the ICCPR. ${ }^{140}$ This was so despite strong dissenting views which pointed to the reasons why the harm might not eventuate, including that the applicant had not yet been 'tried, convicted or sentenced'. ${ }^{141}$ Had the test been one of certainty or necessity, then these factors would have dictated that the claim fail. ${ }^{142}$ However, as one of the dissenting members explained, foreseeability, not certainty, is key:

Although it is impossible to predict a future event, it must be understood that whether or not a person is a victim depends on whether that event is foreseeable - or, in other words, on whether, according to common sense, it may happen, in the absence of exceptional events that prevent it from occurring ....$^{143}$

A similar outcome can be seen where the ECtHR focused squarely on foreseeability. ${ }^{144}$ In the extradition case of Rustamov $v$ Russia, the court stated that:

$[R]$ equesting an applicant to produce 'indisputable' evidence of a risk of illtreatment in the requesting country would be tantamount to asking him to prove the existence of a future event, which is impossible, and would place a clearly disproportionate burden on him. In this respect it further reiterates its constant case-law to the effect that what should be assessed in this type of case are the foreseeable consequences of sending the applicant to the receiving country. ${ }^{145}$

real risk of irreparable harm exists': para 7.2. This was repeated in $R G v$ Denmark, UNHRC, Comm No 2351/2014, UN Doc CCPR/C/115/D/2351/2014 (2015) para 7.4. In Valetov v Kazakhstan, UNHRC, Comm No 2104/2011, UN Doc CCPR/C/110/D/2104/2011 (2014), the UNHRC emphasized the need for the sending State to examine what its authorities knew or should have known: para 14.2. In $X v$ Norway, UNHRC, Comm No 2474/2014, UN Doc CCPR/C/115/D/ 2474/2014 (2015) the UNHRC again cited General Comment 31: para 7.3. In $X v$ Sweden, UNHRC, Comm No 1833/2008, UN Doc CCPR/C/103/D/1833/2008 (2011) the UNHRC simply cited a 'real risk' when finding the claim was made out at para 9.4: see the dissent's critique of what is perceived as low bar (and hence too expansive a view about the scope of implied refoulement). In Jasin v Denmark, UNHRC, Comm No 2360/2014, UN Doc CCPR/C/114/D/2360/2014 (2015) the UNHRC emphasized that the 'risk must be personal and that the threshold for providing substantial grounds to establish that a real risk of irreparable harm exists is high': para 8.3. Here, the UNHRC found that the State party had failed to devote sufficient analysis to "the foreseeable consequences of forcibly returning her to Italy': para 8.9.

140 Ng v Canada, UNHRC, Comm No 469/1991, UN Doc CCPR/C/49/D/469/1991 (1994) para 16.4

141 ibid section E para 5 (Dissenting Opinion of Kurt Herndl).

142 Indeed, this point is borne out in ibid section E para 6.

143 ibid section G para 5 (Dissenting Opinion of Francisco Jos Aguilar Urbina).

144 See eg Trabelsi v Belgium (2015) 60 EHRR 21, para 130, cited with approval in Paposhvili (n 102) para 186. See also Saadi v United Kingdom (2007) 44 EHRR 50, para 142.

${ }_{145}$ Rustamov v Russia, Application No 11209/10, Judgment of 3 July 2012 para 117 (emphasis added). The European Court has affirmed in a couple of cases that speculation is a legitimate part of 
Further, where the UNCAT has ignored the language of 'imminence' that has sometimes been invoked by complainants, ${ }^{146}$ preferring instead to rely on whether a risk of harm is 'real, foreseeable and personal', ${ }^{147}$ the claim has been more likely to succeed. ${ }^{148}$ Indeed, as Wouters observes, although the UNCAT used the terms 'foreseeable' and 'necessary' in the first individual case regarding Article 3 of the CAT, ${ }^{149}$ (thus requiring that the risk of torture be both a foreseeable and necessary consequence of the removal), it has never used the term 'necessary' again. In Haydin $v$ Sweden, the UNCAT pointed out that 'the requirement of necessity and predictability should be interpreted in the light of its general comment on the implementation of Article 3'-in other words, rejecting the notion that these concepts imposed any higher standard than 'real risk'. ${ }^{150}$

If the evidence is strong, an event or occurrence can be foreseeable even if it is not likely to manifest in the short term. A risk can be real notwithstanding the fact that its manifestation is some time away. Of course, foreseeability itself does not provide a template for a definable future period, since the 'temporal limits embodied in the notion of reasonably foreseeable future are unclear', ${ }^{151}$ but it is nonetheless fundamentally different from certainty, likelihood, or probability.

When factors such as necessity are introduced, then the longer the time frame considered, the less likely it is that the long-term harm can be said to amount to a necessary consequence of removal. As such, if extraneous concepts are incorporated into the real risk test in human rights law, it may be less able to accommodate slower-onset forms of harm than the well-founded fear test in refugee law. In other words, the well-founded fear test may have a greater capacity and openness to accommodate longer-range harm than the more

their enquiry. See Saadi (n 144) and Trabelsi (n 144), (the latter of which is cited with approval in Paposhvili on this point).

146 See YBF v Switzerland, UNCAT, Comm No 467/2011, UN Doc CAT/C/50/D/467/2011 (2013); Khademi $v$ Switzerland, UNCAT, Comm No 473/2011, UN Doc CAT/C/53/D/473/2011 (2015); CM v Switzerland, UNCAT, Comm No 355/2008, UN Doc CAT/C/44/D/355/2008 (2010); SM v Switzerland, UNCAT, Comm No 406/2009, UN Doc CAT/C/49/D/406/2009 (2013); ET v Switzerland, UNCAT, Comm No 393/2009, UN Doc CAT/C/48/D/393/2009 (2012); $R D$ v Switzerland, UNCAT, Comm No 426/2010, UN Doc CAT/C/51/D/426/2010 (2013); KN v Switzerland, UNCAT, Comm No 481/2011, UN Doc CAT/C/52/D/481/2011 (2014); $X v$ Switzerland, UNCAT, Comm No 470/2011, UN Doc CAT/C/53/D/470/2011 (2015); MAH v Switzerland, UNCAT, Comm No 438/2010, UN Doc CAT/C/51/D/438/2010 (2013); Ríos v Canada, UNCAT, Comm No 133/1999, UN Doc CAT/C/33/D/133/1999 (2004).

147 In AR v Netherlands, UNCAT, Comm No 203/2002, UN Doc CAT/C/31/D/203/2002 (2003) the UNCAT said: 'in previous decisions, the Committee has determined that the risk of torture must be "foreseeable, real and personal": para 7.3, repeated again at para 7.6. This test is based on the case law of the ECtHR, which has long considered that risk under art 3 ECHR must be foreseeable, real and personal: Soering (n 20) paras 104, 111.

148 We did nevertheless find two cases where imminence was mentioned: Minani (n 69); SPA (n 69).

149 Wouters (n 45) referring at 460 to Mutombo $v$ Switzerland, UNCAT, Comm No 13/1993, UN Doc CAT/C/12/D/13/1993 (1994).

${ }_{150}$ Wouters (n 45) referring at 460 to Haydin $v$ Sweden, UNCAT, Comm No 101/1997, UN Doc CAT/C/21/D/101/1997 (1998).

151 V03/16047 [2004] RRTA 11 (5 January 2004). 
stringent real risk test applied in some of the jurisdictions considered in this article. In order to test this hypothesis, a comprehensive examination of the extent to which imminence has been introduced-explicitly or implicitlyinto national refugee decision-making is ripe, and forms the next stage of our research project.

\section{CONCLUSION}

This article provides the first analysis of the notion of imminence in international refugee and human rights law in assessing the scope of international protection. It examines how acute or 'real' a risk of harm must be before supranational courts and international oversight bodies consider that international protection is warranted. The comprehensive analysis of cases from our selected jurisdictions suggests that the notion of imminence has been introduced into the case law-sometimes explicitly, but most commonly only implicitly. Its application is inconsistent, problematic, and difficult to justify by reference to standard principles of refugee and human rights law. Given that a number of contemporary threats are more likely to raise these issues than ever before, further analysis is warranted, including a comprehensive examination of domestic jurisprudence.

While this article represents part of a larger project, some interim conclusions can be drawn. The role of time as a factor in risk assessment in refugee law and international protection more broadly is radically underdeveloped, both in the jurisprudence and the scholarship. To be clear, we do not believe that the notion of imminence should be used to limit international protection in any way: it should not. However, the point in time at which an event may occur is a contextual factor in assessing risk because it can affect how likely something is to occur. In other words, if a threat is likely to manifest very soon, it may be easier for an individual to argue that he or she faces a real chance of being harmed, since there may be less opportunity for mitigating factors to intervene. By contrast, a threat in the more distant future might be able to be allayed or diminished through intervening measures. Nevertheless, if the risk of harm is distant but very real-for instance, the death penalty has been imposed on a person but it may be years before it is carried out-then protection may be required. The core question in each case is whether the risk is sufficiently real to meet the well-founded fear or real risk tests; any further gloss is a distraction. ${ }^{152}$ Our critique is that because the role and significance of time is

152 By way of analogy, the CJEU explained that in situations of generalized violence, 'the more the applicant is able to show that he is specifically affected by reason of factors particular to his personal circumstances, the lower the level of indiscriminate violence required for him to be eligible for subsidiary protection': Case 465/07 Elgafaji v Staatssecretaris van Justitie [2009] ECR I-00921, para 39. See also H Lambert, 'Causation in International Protection from Armed Conflict' in D Cantor and J-F Durieux (eds), Refuge from Inhumanity? War Refugees and International Humanitarian Law (Brill Nijhoff 2014) 57-78. 
simply not acknowledged by most decision-makers, there is the potential for imminence to creep erroneously into substantive assessments, as has been seen in the examination of jurisprudence above. In our view, both the wellfounded fear and real risk tests are sufficiently open-ended for decisionmakers to be guided by these alone; they do not foreclose a risk of harm simply because it may eventuate further into the future.

It is indisputable that a protection-limiting criterion should not infiltrate decision-making without an explicit consideration of its legal validity and purpose. It is our hope that this initial attempt to parse out the relevant issues in this context will mark the first of many serious analyses. 